\title{
CHANGE ORDER DAN RISIKO CHANGE ORDER PADA PROYEK JALAN DI JAWA BARAT
}

\author{
Mega Waty ${ }^{1)}$ dan Hendrik Sulistio ${ }^{2)}$ \\ 1) Program Sarjana Teknik Sipil, Universitas Tarumanagara, Jakarta, DKI Jakarta \\ 2) Program Doktor Teknik Sipil, Universitas Tarumanagara, Jakarta, DKI Jakarta \\ mega@ft.untar.ac.id
}

\begin{abstract}
Change Order is a change that occurs in a construction project and cannot be avoided. Analysis of change orders on 10 West Java road construction projects examines how causes of change orders vary between upgrade projects versus maintenance projects, and types of construction (e.g. asphalt works, drainage, structures, and widening of road shoulders and grained pavements, restoration of conditions and minor works and daily work). This study also examines the risks posed by change orders by measuring the frequency and average percentage changes in project costs for various types of change orders. The research methodology is by looking for real data on road construction projects from 2014-2018. The result is that the main causes of change orders are consistently terminated contracts, ownerinduced increases, and swelling of contract items, and contract negligence. The risk of a change order is the highest in the work: Hot Asphalt Mixture, Class S Upper, Laston Wear, Stonework, Class B Upper Base, Cement Concrete Pavement, Low quality f'c $15 \mathrm{MPa}$ Concrete, Stone Pairs with Mortar, Embankment Choice, Thermoplastic Road Markings.
\end{abstract}

Keywords: change order, risk, road project

\begin{abstract}
ABSTRAK
Change Order merupakan perubahan yang terjadi pada proyek konstruksi dan tidak bisa dihindari. Analisis change order pada 10 Proyek pembangunan jalan Jawa Barat meneliti bagaimana penyebab change order bervariasi antara proyek peningkatan versus proyek pemeliharaan, dan jenis konstruksi (mis. pekerjaan aspal, drainase, struktur, dan pelebaran bahu jalan dan perkerasan berbutir, pengembalian kondisi dan pekerjaan minor dan pekerjaan harian). Penelitian ini juga meneliti risiko yang ditimbulkan oleh change order dengan mengukur frekuensi dan rata-rata persentase perubahan biaya proyek untuk berbagai jenis change order. Metodologi penelitian dangan mencari data riil proyek pembangunan jalan dari tahun 2014-2018. Hasilnya adalah penyebab utama change order secara konsisten adalah penghilangan kontrak, peningkatan yang disebabkan oleh pemilik, dan membengkaknya item kontrak dan kelalaian kontrak. Risiko change order pada tertinggi pada pekerjaan: Campuran Aspal Panas, Lapis Pondasi Atas Kelas S, Laston Lapis Aus, Pasangan batu, Lapis Pondasi Atas Kelas B, Perkerasan Beton Semen, Beton mutu rendah $f^{\prime} c 15$ MPa, Pasangan Batu dengan Mortar, Timbunan Pilihan, Marka Jalan Termoplastik.
\end{abstract}

Kata kunci: change order, risiko, proyek jalan 


\section{PENDAHULUAN}

Change Order merupakan hal umum yang sering terjadi pada proyek konstruksi. Hampir seluruh proyek yang ada selalu terjadi change order, baik proyek pemerintah maupun proyek swasta. Selama pelaksanaan proyek konstruksi, perubahan itu dapat terjadi baik dari pihak kontraktor maupun dari pemilik (Sulistio \& Waty, 2008). Menurut Goudreau (2001) melaporkan bahwa terdapat 5 kunci yang membebani proyek yakni: pembayaran, otoritas, change order, schedule dari pekerjaan, dan dokumen kontrak. Pada 90 pekerjaan proyek publik (proyek pemerintah) yang diselesaikan sebelum tahun 2000 ditemukan change order yang menyebabkan proyek terlambat dan biaya yang membengkak (Hsieh, Lu, \& Wu, 2004).

Hanna, Camlic, Peterson, \& Nordheim (2002) menyatakan bahwa penyebab yang bervariasi dari suatu proyek dengan probabilitas yang tertinggi yakni dampaknya dan kehilangan produktivitas secara signifikan. Mereka menghitung produktivitas yang hilang sebesar $54.8 \%$ dari suatu proyek yang berdampak secara beragam. Perubahan dalam proyek konstruksi selalu terjadi dan tidak bisa dihindari (Yana, Rusdhi, \& Wibowo, 2015). Change order menyebabkan biaya menyebabkan item kontrak membengkak, kesalahan perencanaan dan kelalaian serta perubahan ruang lingkup yang dapat dikurangi dengan mempertajam hasil akhir perencanaan (Taylor, Uddin, Goodrum, McCoy, \& Shan, 2012). Penelitian Waty \& Sulistio (2020) menyatakan efek change order dari perhitungan change order proyek jalan di Banten adalah tunda tanggal penyelesaian proyek, pembengkakan biaya, menghasilkan klaim dan perselisihan, mempengaruhi kinerja dan moral kerja, serta sebagian besar kontraktor mengeluarkan biaya tambahan. Penyebab change order proyek jalan di Banten adalah:

1. Periode desain yang tidak realistis.

2. Biaya konsutan rendah atau desainer yang kurang berpengalaman.

3. Tidak tersedianya perencanaan proyek secara keseluruhan.

4. Pemilik menginstruksikan modifikasi untuk desain.

5. Pemilik menginstruksikan pekerjaan tambahan

Penelitian ini bertujuan untuk mengetahui penyebab change order dan perubahan change order berdasarkan proyek dan jenis konstruksi dan risiko change order terhadap item pekerjaan di provinsi Jawa Barat. 


\section{KAJIAN PUSTAKA}

Change order adalah persetujuan tertulis untuk memodifikasi, menambah atau memberi alternatif pada pekerjaan yang telah diatur dalam dokumen kontrak antara pemilik dan kontraktor, dimana perubahan tersebut dapat dipertimbangkan untuk masuk dalam ruang lingkup proyek yang asli/orisinil, dan merupakan satusatunya cara yang sah (Fisk \& Reynolds, 1988).

Dalam konstruksi jalan raya dan pemeliharaan jalan raya, kondisi yang tidak terduga sebelumnya, cuaca, dan pasar ekonomi adalah contoh kondisi pekerjaan yang sulit atau mahal bagi pihak transportasi untuk menguranginya. Change Order yang disebabkan oleh membengkaknya item kontrak, kesalahan perencanaan dan kelalaian, dan perubahan ruang lingkup dapat dimitigasi melalui perbaikan perencanaan akhir. Mencegah secara efektif change order dalam konstruksi jalan raya, akan bermanfaat bila mengetahui penyebab utama change order dalam pekerjaan jalan raya. Penelitian sebelumnya di bidang perubahan dalam pembangunan jalan raya telah memberikan kontribusi pengetahuan tentang frekuensi change order (Anastasopoulos, Labi, Bhargava, Bordat, \& Mannering, 2010), dampak change order pada biaya proyek
(Serag, Oloufa, Malone, \& Radwan, 2010), manajemen perubahan dalam desain yang ada dan konstruksi bersamaan (S. Lee, Peña-Mora, \& Park, 2005), pembengkakan biaya dalam konstruksi (Nassar, Nassar, \& Hegab, 2005; Creedy, Skitmore, \& Wong, 2010). Wu, Hsieh, Cheng, \& Lu (2004) dan Wu, Hsieh, \& Cheng (2005) menyelidiki penyebab utama change order pada konstruksi jalan raya Taiwan menggunakan analisis hubungan abu-abu. Penelitian di Kentucky dengan mengidentifikasi penyebab utama change order pada proyek pembangunan dan pemeliharaan jalan raya untuk negara bagian A.S. (Kentucky) menggunakan analisis statistik dari data yang dikumpulkan dari proyek pembangunan dan pemeliharaan jalan Kentucky yakni dampak terkuat di antara konstruksi yang diamati proyek, adalah penyesuaian harga bahan bakar dan aspal, permintaan perubahan yang diinisiasi oleh pemilik, kelalaian kontrak, dan overrun item kontrak (Taylor et al., 2012). Lee (2008) mempelajari data 161 proyek transportasi yang sudah selesai. Hasil penelitian menunjukkan bahwa 95\% dan $100 \%$ proyek jalan dan kereta api, masingmasing, memiliki pembengkakan biaya maksimum sebesar 50\%. Penyebab utama dari pembengkakan biaya ditemukan menjadi perubahan ruang lingkup, keterlambatan selama konstruksi, estimasi yang tidak 
beralasan, penyesuaian biaya proyek, dan tidak ada penggunaan praktis system earned value manajemen. Penelitian Sulistio \& Waty (2008) menunjukkan persentase change order terjadi sebesar $28.26 \%$ proyek di Kalimantan Timur pada pekerjaan galian dan timbunan pada proyek perkerasan jalan. Penelitian Waty \& Sulistio (2020) menyatakan efek change order dari perhitungan change order proyek jalan di Banten adalah: tunda tanggal penyelesaian proyek, pembengkakan biaya, menghasilkan klaim dan perselisihan, mempengaruhi kinerja dan moral kerja, serta sebagian besar kontraktor mengeluarkan biaya tambahan.

\section{METODE PENELITIAN}

Data penelitian didapat dari Dinas Pekerjaan Umum Jawa Barat. Secara total, peneliti mendapatkan 10 data riil proyek yang terdiri dari tahun 2014 hingga tahun 2018 yang dianalisis dalam bentuk hard copy dan soft copy. Data riil berupa addendum kontrak yang berisi kontrak change order. Dalam 10 proyek didapat perubahan proyek yang cukup banyak. Penelitian ini berfokus pada addendum kontrak change order yang berisi perubahan proyek dan alasan perubahannnya dan disajikan dalam setiap catatan change order termasuk berikut informasi yang relevan:
1. Perubahan biaya dan waktu secara keseluruhan.

2. Perubahan biaya per item pekerjaan tertentu.

3. Nilai kontrak asal.

4. Jenis konstruksi.

5. Deskripsi proyek.

6. Alasan untuk masing masing change order.

Identifikasi risiko change order dengan mengacu kepada item pekerjaan konstruksi yang mengalami penghilangan kontrak, item kontrak overrun dan peningkatan pekerjaan yang disebabkan oleh pemilik yang semuanya ini didapat dari data addendum kontrak change order.

\section{FCO (Frequency Change Order)} Index ini mengukur rata-rata frekuensi dari jenis pekerjaan proyek yang mengalami change order (Hsieh et al., 2004). FCO = (total frekuensi change order jenis pekerjaan proyek/jumlah seluruh proyek) $\mathrm{x}$ $100 \%$.

\section{COR (Change Order Ratio)}

Index ini mengukur dari total biaya varian dari proyek yang terjadi change order (Hsieh et al., 2004). $\mathrm{COR}=$ (jumlah dari nilai tambah dan kurang untuk proyek yang dilakukan change order/harga kontrak asal) $\mathrm{x}$ $100 \%$. 
Nilai COR ini merupakan nilai perubahan pada proyek yang mengalami change order. Misalnya nilai perubahan proyek adalah Rp.200,000.00. Nilai proyek asal Rp.1,000,000.00. Maka nilai COR adalah sebesar Rp.200,000.00/ Rp. $1,000,000.00 \times 100 \%=20 \%$.

Perubahan proyek ini dapat penambahan pekerjaan, dan pengurangan pekerjaan. Dalam hal ini setiap penambahan atau pengurangan pekerjaan dianggap perubahan proyek. Jadi yang dihitung hanya perubahan proyek saja.

Risiko change order didapat dengan mengalikan frekuensi change order (FCO) dengan rata rata perubahan change order (COR) pada setiap proyek pada setiap jenis pekerjaan konstruksi dibawah ini sebagai berikut (Taylor et al., 2012):

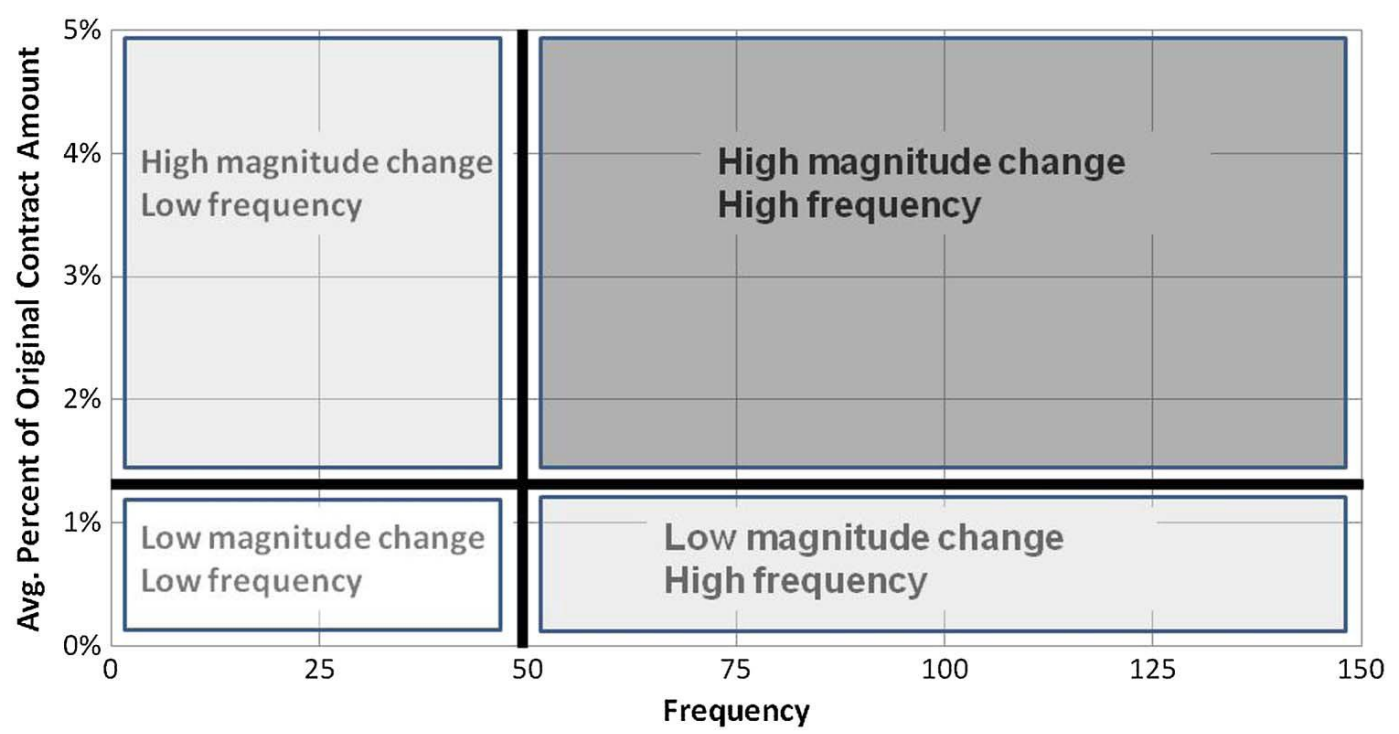

Gambar 1. Risiko Berdasarkan Item Pekerjaan

(Sumber: Taylor et al., 2012)

Data deskriptif menunjukkan

beberapa hal yang dapat menjelaskan data change order. Data paket dan nilai kontrak terdapat pada Tabel 1 yang menunjukkan bahwa terdapat sepuluh paket proyek jalan di Provinsi Jawa Barat.
Perhitungan kontrak dan kontrak addendum didapat dari data kontrak change order yang di dapat dari owner yakni Dinas Pekerjaan Umum Perumahan Rakyat tahun anggaran 2014-2018. 
Tabel 1. Data Paket dan Nilai Kontrak

\begin{tabular}{clrrc}
\hline No & Paket & Kontrak (Rp.) & Kontrak Addendum (Rp.) & Tahun \\
\hline 1 & Jalan 1 & $30,636,607,000$ & $34,713,981,000$ & 2014 \\
2 & Jalan 2 & $32,625,419,000$ & $35,853,368,000$ & 2014 \\
3 & Jalan 3 & $11,425,860,000$ & $11,425,860,000$ & 2016 \\
4 & Jalan 4 & $13,402,830,000$ & $13,402,830,000$ & 2015 \\
5 & Jalan 5 & $38,825,312,000$ & $42,692,277,000$ & 2014 \\
6 & Jalan 6 & $37,006,518,000$ & $40,707,170,611$ & 2018 \\
7 & Jalan 7 & $26,090,000,000$ & $28,614,697,000$ & 2015 \\
8 & Jalan 8 & $25,484,257,000$ & $25,484,257,000$ & 2018 \\
9 & Jalan 9 & $21,544,837,000$ & $21,544,837,000$ & 2013 \\
10 & Jalan 10 & $74,448,316,800$ & $81,893,148,480$ & 2017 \\
\hline
\end{tabular}

Sumber: Dinas PUPR

\section{HASIL DAN PEMBAHASAN}

Tabel 2 menunjukkan terdapat enam item penambahan dana proyek dan empat paket proyek yang balance budget (tidak ada perubahan dana kontrak meskipun terdapat perubahan pekerjaan).

Tabel 3 menunjukkan perubahan terbesar pada masing masing proyek jalan yang berbeda antara proyek satu dengan proyek lainnya, antara lain proyek jalan 1 menghasilkan perubahan terbesar pada pekerjaan Laston Lapis Aus Modifikasi (AC-WC) Mod (gradasi halus/ kasar) dan proyek jalan 2 menghasilkan perubahan terbesar sebesar $13.3 \%$ pada Lapis Aus Modifikasi (AC-WC) (gradasi halus/ kasar). Lebih jelasnya dapat dilihat pada Tabel 3.

Tabel 2. Paket berdasarkan Balance dan Penambahan Dana

\begin{tabular}{cccrcc}
\hline No & Paket & Kontrak (Rp.) & Kontrak Add (Rp.) & Tahun & Keterangan \\
\hline 1 & Jalan 1 & $30,636,607,000$ & $34,713,981,000$ & 2014 & Penambahan dana \\
2 & Jalan 2 & $32,625,419.000$ & $35,853,368,000$ & 2014 & Penambahan dana \\
3 & Jalan 3 & $11,425,860,000$ & $11,425,860,000$ & 2016 & Balance Budget \\
4 & Jalan 4 & $13,402,830,000$ & $13,402,830,000$ & 2015 & Balance Budget \\
5 & Jalan 5 & $38,825,312,000$ & $42,692,277,000$ & 2014 & Penambahan dana \\
6 & Jalan 6 & $37,006,518,000$ & $40,707,170,611$ & 2018 & Penambahan dana \\
7 & Jalan 7 & $26,090,000,000$ & $28,614,697,000$ & 2015 & Penambahan dana \\
8 & Jalan 8 & $25,484,257,000$ & $25,484,257,000$ & 2018 & Balance budget \\
9 & Jalan 9 & $21,544,837,000$ & $21,544,837,000$ & 2013 & Balance budget \\
10 & Jalan 10 & $74,448,316,800$ & $81,893,148,480$ & 2017 & Penambahan Dana \\
\hline
\end{tabular}


Tabel 3. Perubahan Terbesar Masing Masing Proyek Jalan

\begin{tabular}{clcl}
\hline No & Nama Proyek & $\begin{array}{c}\text { Perubahan } \\
\text { terbesar }(\%)\end{array}$ & \multicolumn{1}{c}{ Pekerjaan } \\
\hline 1 & Jalan 1 & 9.73 & $\begin{array}{l}\text { Laston Lapis Aus Modifikasi (AC- WC) Mod } \\
\text { (gradasi halus/kasar). }\end{array}$ \\
2 & Jalan 2 & 13.3 & $\begin{array}{l}\text { Laston Lapis Aus Modifikasi (AC-WC) Gradasi } \\
\text { halus/ kasar }\end{array}$ \\
3 & Jalan 3 & 3.18 & Expantion Joint Tipe Alphabetic Plug, Moveable. \\
4 & Jalan 4 & 2.29 & Saluran Berbentuk U Tipe DS 2 \\
5 & Jalan 5 & 2.29 & Aspal Modifikasi : 3 Elastomer \\
6 & Jalan 6 & 12.23 & Laston Lapis Aus Modifikasi AC-BC) L \\
7 & Jalan 7 & 2.08 & Kerb Pracetak Jenis 2 \\
8 & Jalan 8 & 6.37 & Laston Lapis Aus (AC-WC \\
9 & Jalan 9 & 1.46 & Daur ulang campuran beraspal dingin dengan \\
10 & Jalan 10 & 1.78 & Pemancangan tiang pancang \\
\hline
\end{tabular}

Perubahan total change order yang terkecil pada Proyek Jalan 3 sebesar terdapat pada Tabel 4 dimana yang terbesar Rp.938,748,658.00. Alasan perubahan pada proyek Jalan 2 yang terbesar change order yang terbesar adalah Rp.21,779,486,925.00 sebesar $60.74 \%$ dan meningkatnya item kontrak konstruksi yang kedua yakni Rp.18,198,976,747.00 sehingga terjadi penambahan dana, pemilik sebesar $46.87 \%$ pada proyek Jalan 6 dan meminta perubahan dan kelalaian kontrak.

Tabel 4. Peringkat Perubahan Total Proyek Jawa Barat

\begin{tabular}{clcrc}
\hline No & Nama Proyek & $\begin{array}{c}\text { Perubahan } \\
\text { Total }(\%)\end{array}$ & Nilai Perubahan (Rp) & Ranking \\
\hline 1 & Proyek Jalan 2 & 60.74 & $21,779,486,925$ & 1 \\
2 & Proyek Jalan 6 & 46.87 & $18,198,976,747$ & 2 \\
3 & Proyek Jalan 10 & 17.21 & $9,741,596,416$ & 3 \\
4 & Proyek Jalan 1 & 31.58 & $9,677,797,785$ & 4 \\
5 & Proyek Jalan 8 & 34.78 & $9,133,785,070$ & 5 \\
6 & Proyek Jalan 4 & 24.23 & $3,248,175,851$ & 6 \\
7 & Proyek Jalan 5 & 19.19 & $2,857,247,931$ & 7 \\
8 & Proyek Jalan 7 & 10.11 & $2,572,003,077$ & 8 \\
9 & Proyek Jalan 9 & 7.49 & $1,013,620,519$ & 9 \\
10 & Proyek Jalan 3 & 8.21 & $938,748,658$ & 10 \\
\hline
\end{tabular}




\subsection{Analisa Rata Rata Perubahan Seluruh Proyek}

Perhitungan rata rata perubahan dilihat dari 10 proyek per masing masing item pekerjaan. Masing masing item pekerjaan di hitung semuanya baru dilakukan rekapitulasi masing masing item pekerjaan. Masing masing item pekerjaan lalu di rata ratakan dari 10 proyek jalan.

Misalkan dalam suatu proyek ada 50 perubahan item pekerjaan. Masing masing perubahan dihitung. Lalu dilakukan rekapitulasi per masing masing pekerjaan sehingga mendapatkan sejumlah persentase perubahan. Lalu dibagi ke pada 10 proyek. Sehingga menghasilkan rata rata persentase perubahan. Dari rata rata persentase perubahan diranking dan didapat hasil yang terbesar sebesar $6.34 \%$ pada pekerjaan aspal panas. Rata rata perubahan change order yang diranking dapat dilihat pada Tabel 5.

Tabel 5. Rekapitulasi Ranking Rata Rata Perubahan Proyek

\begin{tabular}{rlc}
\hline No & \multicolumn{1}{c}{ Item Pekerjaan } & $\begin{array}{c}\text { \% rata rata } \\
\text { perubahan }\end{array}$ \\
\hline 1 & Campuran Aspal Panas untuk pekerjaan minor & 6.34 \\
2 & Pengecatan sederhana/elemen beton & 4.43 \\
3 & Lapis Pondasi Atas Kelas S & 4.33 \\
4 & Laston Lapis Aus & 3.75 \\
5 & Laston Lapis Perata ( AC-WC) L & 3.35 \\
6 & Pasangan batu & 2.79 \\
7 & Lapis Pondasi Atas Kelas B & 2.20 \\
8 & Perkerasan beton semen & 1.60 \\
9 & Aspal Modifikasi & 1.56 \\
10 & Beton mutu rendah f'c 15 MPa & 1.46 \\
11 & Pengecatan kerb dan median & 1.39 \\
12 & Pasangan batu dengan mortar & 1.30 \\
13 & Laston Lapis Antara (AC-BC) L & 1.22 \\
14 & Timbunan Pilihan & 1.07 \\
15 & Marka Jalan Termoplastik & 1.07 \\
16 & Expantion Joint Tipe Asphatic plug food, type asphatic flug fixed & 1.06 \\
\hline
\end{tabular}




\subsection{Analisis Change Order oleh Proyek Peningkatan Versus Pekerjaan Pemeliharaan Proyek}

Proyek yang diamati dibagi menjadi proyek peningkatan dan proyek pemeliharaan jalan berdasarkan jenis konstruksi. Terdapat 7 proyek peningkatan jalan dan 3 proyek pemeliharaan jalan dari 10 proyek yang diteliti. Klasifikasi proyek dalam penelitian ini dibagi menjadi 7 proyek peningkatan jalan dan 3 proyek pemeliharaan jalan yang dapat dilihat pada Tabel 6. Terdapat enam kontrak penambahan dana dalam penelitian ini yang menunjukkan bahwa dengan adanya change order mengakibatkan meningkatnya baik volume maupun jumlah item pekerjaan konstruksi sehingga terjadi penambahan dana yang menyebabkan meningkatnya biaya kontrak pelaksanaan pekerjaan konstruksi. Sehingga disimpulkan bahwa perubahan terbesar pada addendum kontrak dalam penelitian ini adalah meningkatnya item kontrak, pemilik meminta perubahan dan kelalaian kontrak.

Tabel 6. Klasifikasi Proyek Peningkatan dan Proyek Pemeliharaan

\begin{tabular}{ccrrrl}
\hline No & Paket & Kontrak Asal (Rp) & $\begin{array}{c}\text { Kontrak } \\
\text { Addendum (Rp) }\end{array}$ & Tahun & Keterangan \\
\hline 1 & Jalan 1 & $30,636,607,000$ & $34,713,981,000$ & 2014 & Peningkatan \\
2 & Jalan 2 & $32,625,419.000$ & $35,853,368,000$ & 2014 & Peningkatan \\
3 & Jalan 3 & $11,425,860,000$ & $11,425,860,000$ & 2016 & Peningkatan \\
4 & Jalan 4 & $13,402,830,000$ & $13,402,830,000$ & 2015 & Peningkatan \\
5 & Jalan 5 & $38,825,312,000$ & $42,692,277,000$ & 2014 & Peningkatan \\
6 & Jalan 6 & $37,006,518,000$ & $40,707,170,611$ & 2018 & Pemeliharaan \\
7 & Jalan 7 & $26,090,000,000$ & $28,614,697,000$ & 2015 & Peningkatan \\
8 & Jalan 8 & $25,484,257,000$ & $25,484,257,000$ & 2018 & Pemeliharaan \\
9 & Jalan 9 & $21,544,837,000$ & $21,544,837,000$ & 2013 & Peningkatan \\
10 & Jalan 10 & $74,448,316,800$ & $81,893,148,480$ & 2017 & Pemeliharaan \\
\hline
\end{tabular}

Perubahan total proyek peningkatan menunjukkan proyek jalan 1 terbesar perubahan total proyek berdasarkan nominalnya tetapi untuk ketiga proyek pemeliharaan pada proyek jalan 6 , proyek jalan 10 dan proyek jalan 8 menempati urutan ke dua, ke tiga dan ke lima dalam perubahan total proyek, yang menunjukkan bahwa proyek pemeliharaan juga mengalami perubahan total terbesar meskipun hanya ada tiga proyek saja di dalamnya yang dapat dilihat pada Tabel 7. 
Tabel 7. Perubahan Total Proyek Peningkatan versus Proyek Pemeliharaan

\begin{tabular}{clcrcc}
\hline No & Nama Proyek & $\begin{array}{c}\text { Perubahan } \\
\text { Total }(\%)\end{array}$ & $\begin{array}{c}\text { Nilai Perubahan } \\
(\text { Rp })\end{array}$ & Jenis Proyek & Ranking \\
\hline 1 & Proyek Jalan 2 & 60.74 & $21,779,486,925$ & Peningkatan & 1 \\
2 & Proyek Jalan 6 & 46.87 & $18,198,976,747$ & Pemeliharaan & 2 \\
3 & Proyek Jalan 10 & 17.21 & $9,741,596,416$ & Pemeliharaan & 3 \\
4 & Proyek Jalan 1 & 31.58 & $9,677,797,785$ & Peningkatan & 4 \\
5 & Proyek Jalan 8 & 34.78 & $9,133,785,070$ & Pemeliharaan & 5 \\
6 & Proyek Jalan 4 & 24.23 & $3,248,175,851$ & Peningkatan & 6 \\
7 & Proyek Jalan 5 & 19.19 & $2,857,247,931$ & Peningkatan & 7 \\
8 & Proyek Jalan 7 & 10.11 & $2,572,003,077$ & Peningkatan & 8 \\
9 & Proyek Jalan 9 & 7.49 & $1,013,620,519$ & Peningkatan & 9 \\
10 & Proyek Jalan 3 & 8.21 & $938,748,658$ & Peningkatan & 10 \\
\hline
\end{tabular}

Perubahan total pada seluruh proyek kemudian ditabulasikan ke dalam sub bidang pekerjaan, dari per bagian item pekerjaan menjadi sub bidang item pekerjaan, sehingga dapat diklasifikasikan berdasarkan lima kategori bidang pekerjaan per paket peningkatan jalan dan paket pemeliharaan jalan. Lima kategori itu antara lain: pekerjaan drainase, pekerjaan struktur, pekerjaan aspal, dan pekerjaan pelebaran bahu jalan dan perkerasan berbutir. Kemudian hasilnya ditabulasikan dalam bentuk Tabel 8 di bawah ini.

Tabel 8. Perubahan Total Berdasarkan Jenis Konstruksi

\begin{tabular}{|c|c|c|c|c|}
\hline No & Paket & Jenis konstruksi & $\%$ & Ranking \\
\hline 1 & Peningkatan & Drainase & 13.3 & 1 \\
\hline 2 & Pemeliharaan & Aspal & 12.23 & 2 \\
\hline 3 & Peningkatan & Aspal & 9.73 & 3 \\
\hline 4 & Pemeliharaan & Aspal & 6.37 & 4 \\
\hline 5 & Peningkatan & Struktur & 3.18 & 5 \\
\hline 6 & Peningkatan & Drainase & 2.29 & 6 \\
\hline 7 & Peningkatan & Aspal & 2.29 & 7 \\
\hline 8 & Peningkatan & Pengembalian kondisi dan pekerjaan minor & 2.08 & 8 \\
\hline 9 & Pemeliharaan & Struktur & 1.78 & 9 \\
\hline 10 & Peningkatan & Pelebaran bahu jalan dan perkerasan berbutir & 1.46 & 10 \\
\hline
\end{tabular}




\subsection{Analisis Change Order berdasarkan Jenis Konstruksi}

Mengetahui penyebab change order dalam kaitannya dengan pengelompokkan jenis konstruksi memungkinkan untuk memahami tidak hanya yang mana jenis change order yang mana konstruksi terjadi lebih sering, tetapi juga penyebab change order pada jenis konstruksi tertentu. Penulis mengelompokkan change order kelima kategori untuk memungkinkan perbandingan yang lebih umum dari change order di antara pekerjaan jenis. Jenis konstruksi pekerjaan meliputi:

1. Pekerjaan drainase

2. Pekerjaan aspal
3. Pekerjaan struktur

4. Pekerjaan pelebaran bahu jalan dan perkerasan berbutir

5. Pekerjaan pengembalian kondisi dan pekerjaan minor

Dari kelima kategori tersebut didapat perubahan terbesar pada masing masing proyek beserta dapat dilihat pada Tabel 9 dan Tabel 10. Dari 10 proyek didapat perubahan terbesar pada jenis pekerjaan drainase sebesar $13.3 \%$ pada proyek jalan 2 dan pada proyek jalan 6 terdapat perubahan sebesar $12.23 \%$. Alasan perubahan ini adalah meningkatnya item kontrak, pemilik meminta perubahan dan kelalaian kontrak.

Tabel 9. Perubahan Change Order Terbesar Masing-Masing Proyek Berdasarkan Jenis Konstruksi

\begin{tabular}{|c|c|c|c|}
\hline No & Paket & Jenis Konstruksi & $\%$ perubahan \\
\hline 1 & Jalan 1 & Aspal & 9.73 \\
\hline 2 & Jalan 2 & Drainase & 13.3 \\
\hline 3 & Jalan 3 & Struktur & 3.8 \\
\hline 4 & Jalan 4 & Drainase & 2.29 \\
\hline 5 & Jalan 5 & Aspal & 2.29 \\
\hline 6 & Jalan 6 & Aspal & 12.23 \\
\hline 7 & Jalan 7 & Pengembalian kondisi dan pekerjaan minor & 2.08 \\
\hline 8 & Jalan 8 & Aspal & 6.37 \\
\hline 9 & Jalan 9 & Pelebaran bahu jalan dan perkerasan berbutir & 1.46 \\
\hline 10 & Jalan 10 & Struktur & 1.76 \\
\hline
\end{tabular}

Tabel 10. Rata Rata Perubahan Change Order Proyek Berdasarkan Jenis Konstruksi

\begin{tabular}{clc}
\hline \multirow{2}{*}{ No } & \multicolumn{1}{c}{ Jenis Pekerjaan } & $\begin{array}{c}\text { Perubahan rata rata } \\
(\%)\end{array}$ \\
\hline 1 & Drainase & 2.54 \\
2 & Pekerjaan pelebaran bahu jalan dan perkerasan berbutir & 8.41 \\
3 & Aspal & 17.99 \\
4 & Struktur & 10.31 \\
5 & Pengembalian kondisi dan pekerjaan minor & 14.38 \\
\hline
\end{tabular}


Perhitungan ini merupakan perhitungan berdasarkan lima kategori pekerjaan yang sudah penulis tuliskan di atas dimana antara lain adalah pekerjaan aspal dan pekerjaan drainase. Dari kelima kategori pekerjaan rata rata perubahan change order terbesar pada pekerjaan Aspal sebesar $17.99 \%$ diikuti dengan pekerjaan pengembalian kondisi dan pekerjaan minor sebesar $14.38 \%$ dan seterusnya sampai yang terkecil pada pekerjaan drainase sebesar $2.54 \%$. Alasan perubahan ini adalah meningkatnya item kontrak, pemilik meminta perubahan dan kelalaian kontrak.

\subsection{Analisis Change Order Pekerjaan Tambah}

Change order disebabkan oleh pemilik yang meminta perubahan, maka terjadi penambahan pekerjaan yang menyebabkan terjadinya change order. Dengan terjadi penambahan maka terjadi pula peningkatan item kontrak. Perubahan pekerjaan terjadi pada 10 proyek yang telah diteliti, dan hasilnya dapat dilihat pada data dibawah ini. Perubahan terbesar pada Proyek Jalan 6 sebesar $39.84 \%$ dan terkecil pada proyek Jalan 3 sebesar $4.11 \%$ seperti terlihat pada Tabel 11.

Total Pekerjaan Tambah nominal terbesar dalam rupiah pada proyek Jalan 2 dalam rupiah dan yang terkecil pada Proyek Jalan 3 seperti yang terlihat pada Tabel 11 . Alasan change order adalah kelalaian kontrak, pemilik meminta perubahan, dan over-run pada item kontrak.

Tabel 11. Nominal terbesar dalam Total Pekerjaan Tambah

\begin{tabular}{clcrc}
\hline No & Nama Proyek & $\begin{array}{c}\text { Total Pekerjaan } \\
\text { Tambah }\end{array}$ & $\begin{array}{c}\text { Nilai Perubahan } \\
(\text { Rp })\end{array}$ & Ranking \\
\hline 1 & Jalan 6 & 39.84 & $5,798,560,347$ & 1 \\
2 & Jalan 2 & 35.32 & $11,523,297,991$ & 2 \\
3 & Jalan 9 & 34.26 & $7,381,261,156$ & 3 \\
4 & Jalan 1 & 22.47 & $6,883,126,495$ & 4 \\
5 & Jalan 5 & 14.94 & $5,798,560,347$ & 5 \\
6 & Jalan 10 & 8.56 & $4,848,458,368$ & 6 \\
7 & Jalan 7 & 10.11 & $2,637,699,000$ & 7 \\
8 & Jalan 8 & 13.96 & $1,889,204,598$ & 8 \\
9 & Jalan 4 & 12.12 & $1,624,154,939$ & 9 \\
10 & Jalan 3 & 4.11 & $469,374,329$ & 10 \\
\hline
\end{tabular}


4.5 Analisis Change Order Pekerjaan Kurang

Change order disebabkan oleh pemilik yang meminta perubahan, maka terjadi pengurangan pekerjaan yang menyebabkan terjadinya change order. Dengan terjadi pengurangan maka terjadi penghilangan item kontrak dan pengurangan item kontrak proyek. Perubahan pekerjaan terjadi pada 10 proyek yang telah diteliti, dan hasilnya dapat dilihat pada data dibawah ini. Perubahan terbesar pada Proyek Jalan 2 sebesar $25.42 \%$ dan terkecil pada proyek Jalan 9 sebesar 4\% seperti terlihat pada Tabel 12 . Total Pekerjaan Tambah nominal terbesar dalam rupiah pada proyek Jalan 2 dalam rupiah dan yang terkecil pada Proyek Jalan 3 seperti yang terlihat pada Tabel 12 .

Tabel 12. Urutan Total Change Order Pekerjan Kurang

\begin{tabular}{ccrc}
\hline Nama Proyek & Perubahan Pekerjaan Kurang $(\%)$ & Harga Perubahan $(\mathrm{Rp})$. & Peringkat \\
\hline Jalan 2 & 25.42 & $8,295,339,034$ & 1 \\
Jalan 6 & 17.03 & $4,813,233,384$ & 2 \\
Jalan 8 & 20.18 & $2,816,214,018$ & 3 \\
Jalan 1 & 9.12 & $2,794,364,924$ & 4 \\
Jalan 5 & 4.97 & $1,931,559,272$, & 5 \\
Jalan 4 & 12.11 & $1,624,154,939$ & 6 \\
Jalan 3 & 4.11 & $469,374,328$ & 7 \\
Jalan 7 & 0.21 & $56,928,380$ & 8 \\
Jalan 10 & 9 & $50,106,108$ & 9 \\
Jalan 9 & 4 & $8,753,667$ & 10 \\
\hline
\end{tabular}

Alasan change order adalah kelalaian kontrak, pemilik meminta perubahan, dan pengurangan dan penghilangan item kontrak.

Berdasarkan analisis yang disajikan pada poin diatas maka didapat bahwa pekerjaan tambah, dan perubahan pekerjaan disebabkan oleh ini kelalaian kontrak, pemilik meminta perubahan, dan overrun pada item kontrak. Alasan pekerjaan kurang change order disebabkan oleh kelalaian kontrak, pemilik meminta perubahan, dan pengurangan dan penghilangan item kontrak. Identifikasi dari alasan perubahan kontrak change order adalah kelalaian kontrak, pemilik meminta perubahan, dan overrun pada item kontrak dan pengurangan item kontrak dan penghilangan item kontrak. 


\subsection{Identifikasi Change Order}

Tren yang jelas muncul yang mengidentifikasi change order terkait dengan penghilangan kontrak, kontrak item overrun, dan peningkatan perubahan yang diinduksi pemilik saat mengerahkan dampak keseluruhan terbesar di antara semua change order terkait rekayasa pada proyek yang diamati. Data change order rata rata untuk pekerjaan terdapat pada pekerjaan seperti pada Tabel 5 di atas.

\subsection{Frekuensi Change Order}

Frekuensi change order berdasarkan frekuensi yang sering muncul dalam pekerjaan change order pada proyek Jalan di Jawa Barat didapat hasil yang terbesar yakni pasangan batu dan beton mutu rendah f'c 15 Mpa dan pasangan batu dengan mortar sebesar $90 \%$ yang dapat dilihat pada Tabel 13.

Cara menghitung FCO adalah FCO = (total frekuensi change order jenis pekerjaan proyek/jumlah seluruh proyek) $\mathrm{x}$ 100\%. Contoh perhitungan adalah pekerjaan campuran aspal, dimana total frekuensi 10 proyek $=8 / 10$ proyek x $100 \%$ $=80 \%$. Begitu pula seterusnya untuk seluruh frekuensi change order yang lain yang dapat dilihat pada Tabel 13.

Tabel 13. Frekuensi Change Order

\begin{tabular}{clc}
\hline No & \multicolumn{1}{c}{ Pekerjaan } & FCO $(\%)$ \\
\hline 1 & Campuran Aspal Panas untuk pekerjaan minor & 80 \\
2 & Pengecatan sederhana/elemen beton & 20 \\
3 & Lapis Pondasi Atas Kelas S & 60 \\
4 & Laston Lapis Aus & 70 \\
5 & Laston Lapis Perata (AC-WC) L & 20 \\
6 & Pasangan batu & 90 \\
7 & Lapis Pondasi Atas Kelas B & 70 \\
8 & Perkerasan beton semen & 80 \\
9 & Aspal Modifikasi & 30 \\
10 & Beton mutu rendah f'c 15 MPa & 90 \\
11 & Pengecatan kerb dan median & 40 \\
12 & Pasangan batu dengan mortar & 90 \\
13 & Laston Lapis Antara (AC-BC) L & 10 \\
14 & Timbunan Pilihan & 80 \\
15 & Marka Jalan Termoplastik & 80 \\
16 & Expantion Joint Tipe Asphatic plug food, type asphatic flug fixed & 20 \\
\hline
\end{tabular}


Setelah item baris diurutkan ke dalam salah satu dari 16 kategori, informasi tentang risiko yang ditimbulkan oleh setiap item baris ke kinerja kontrak dikuantifikasi oleh frekuensi change order item dalam setiap kategori dan persentase rata-rata dari jumlah kontrak.

\subsection{Risiko Change Order}

Risiko change order didapat dengan mengalikan frekuensi change order dengan rata rata perubahan change order maka didapat hasilnya yang digambarkan pada Gambar 2, dimana gambar asal (Gambar 1) berdasarkan penelitian Taylor et al., (2012).

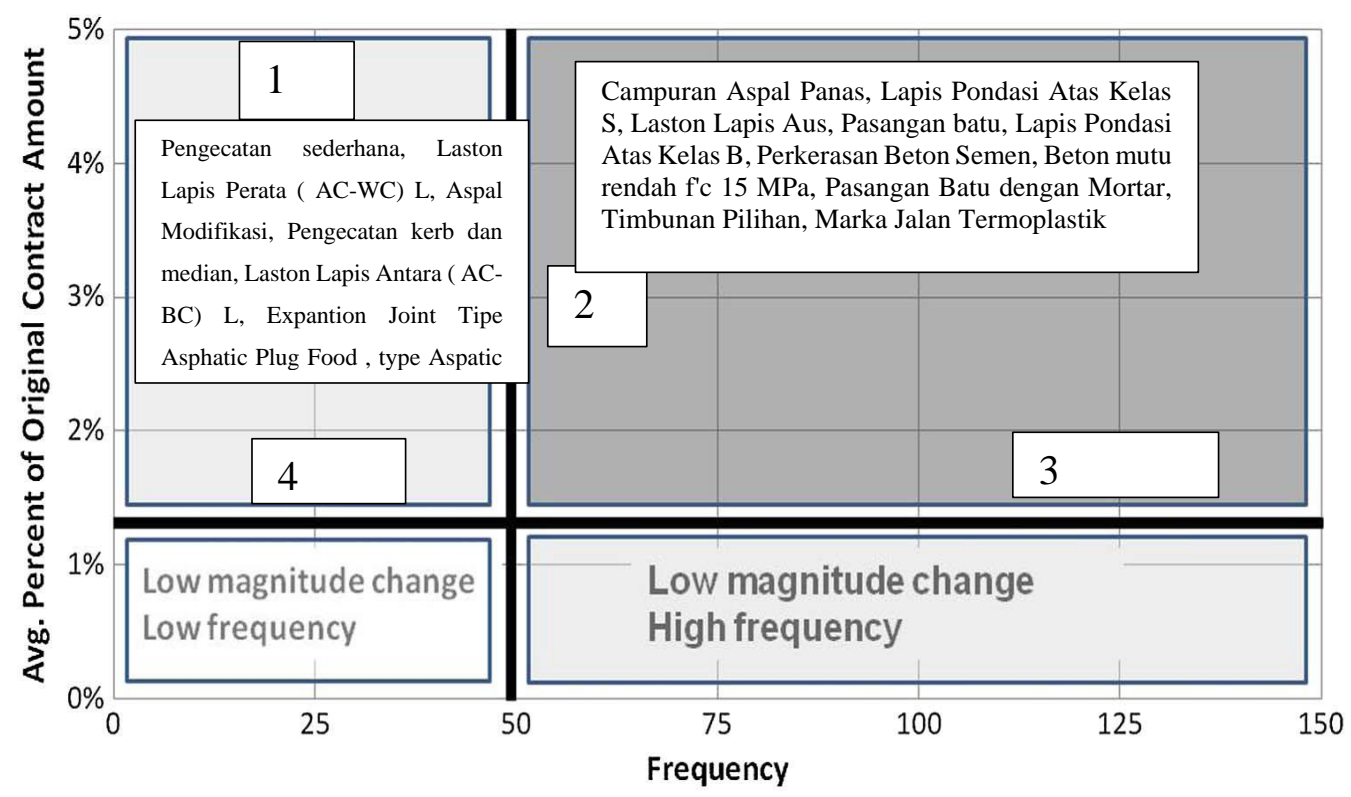

Gambar 2. Hasil Risiko Berdasarkan Analisis Pekerjaan

Pada Gambar 2 didapat hasil sebagai berikut:

1. Pekerjaan campuran aspal panas, lapis pondasi atas kelas $\mathrm{S}$, laston lapis aus, pasangan batu, lapis pondasi atas kelas B, perkerasan beton semen, beton mutu rendah 1 f'c $15 \mathrm{MPa}$, pasangan batu dengan mortar, timbunan pilihan, marka jalan termoplastik berada pada tinggi perubahan dan tinggi frekuensi pada kuadran 2.
2. Pekerjaaan pengecatan sederhana, laston lapis perata (AC-WC) L, aspal modifikasi, pengecatan kerb dan median, laston lapis antara (AC-BC) L, expantion joint tipe asphatic plug food, type aspatic flug fixed berada pada tinggi perubahan dan rendah frekuensi pada kuadran 1.

Dari perspektif manajemen risiko, kategori yang termasuk dalam kuadran 
kanan atas (2) harus menerima perhatian mitigasi risiko terlebih dahulu, karena mereka lebih sering terjadi dan mengakibatkan kenaikan biaya yang besar.

Kategori jatuh dalam kiri atas (2) dan kanan bawah (3) kuadran harus menerima perhatian mitigasi risiko selanjutnya, karena mereka sering terjadi dengan kenaikan biaya rendah atau kurang sering dengan kenaikan biaya tinggi ketika terjadi

\section{SIMPULAN DAN SARAN}

\subsection{Simpulan}

Berdasarkan penelitian diatas maka disimpulkan sebagai berikut:

1. Penyebab change order adalah meningkatnya item kontrak, pemilik meminta perubahan dan kelalaian kontrak, pengurangan dan penghilangan item kontrak.

2. Perubahan change order berdasarkan proyek peningkatan terbesar pada Proyek Jalan 2 sebesar $60.746 \%$.

3. Perubahan change order pada jenis konstruksi terbesar pada jenis Drainase sebesar 13.3\%.

4. Risiko change order terbesar pada Gambar 2 kuadran ke 2, antara lain pekerjaan campuran aspal panas, lapis pondasi atas kelas S, laston lapis aus, pasangan batu, lapis pondasi atas kelas B, perkerasan beton semen, beton mutu rendah f'c $15 \mathrm{MPa}$, pasangan batu dengan mortar, timbunan pilihan, marka jalan termoplastik.

\subsection{Saran}

Berdasarkan penelitian diatas maka saran penulis adalah:

1. Lebih memperhatikan kontrak proyek peningkatan jalan.

2. Lebih memperhatikan klausul dan isi kontrak sebelum ditanda tangani.

3. Lebih memperhatikan pada jenis konstruksi drainase.

4. Lebih memperhatikan pekerjaan yang mengandung risiko change order terbesar seperti pekerjaan pekerjaan campuran aspal panas, lapis pondasi atas kelas $\mathrm{S}$, laston lapis aus, pasangan batu, lapis pondasi atas kelas $\mathrm{B}$, perkerasan beton semen, beton mutu rendah $\mathrm{f}^{\prime} \mathrm{c} 15 \mathrm{MPa}$, pasangan batu dengan mortar, timbunan pilihan, marka jalan termoplastik.

5. Lebih memperhatikan kontrak proyek peningkatan jalan.

6. Lebih memperhatikan klausul dan isi kontrak sebelum ditanda tangani. 


\section{DAFTAR PUSTAKA}

Anastasopoulos, P. C., Labi, S., Bhargava, A., Bordat, C., \& Mannering, F. L. (2010). Frequency of Change Orders in Highway Construction Using Alternate Count-Data Modeling Methods. Journal of Construction Engineering and Management, 136(8), 886-893. https://doi.org/10.1061/_ASCECO.1 943-7862.0000198

Creedy, G. D., Skitmore, M., \& Wong, J. K. W. (2010). Evaluation of Risk Factors Leading to Cost Overrun in Delivery of Highway Construction Projects. Journal of Construction Engineering and Management, 136(5), 528-537. https://doi.org/https://doi.org/10.106 1/(ASCE)CO.1943-7862.0000160

Fisk, E. R., \& Reynolds, W. D. (1988). Construction Project Administration. Wiley.

Hanna, A. S., Camlic, R., Peterson, P. A., \& Nordheim, E. V. (2002). Quantitative Definition of Projects Impacted by Change Orders. Journal of Construction Engineering and Management, 128(1), 57-64. https://doi.org/10.1061/(ASCE)07339364(2002)128:1(57)

Hsieh, T., Lu, S., \& Wu, C. (2004). Statistical analysis of causes for change orders in metropolitan public works. International Journal of Project Management, 22(8), 679686.

https://doi.org/10.1016/j.ijproman.20 04.03.005

Lee, J. K. (2008). Cost Overrun and Cause in Korean Social Overhead Capital Projects: Roads, Rails, Airports, and Ports. Journal of Urban Planning and Development, 134(2), 59-62. https://doi.org/https://doi.org/10.106 1/(ASCE)0733-9488(2008)134:2(59)
Lee, S., Peña-Mora, F., \& Park, M. (2005). Quality and Change Management Model for Large Scale Concurrent Design and Construction Projects. Journal of Construction Engineering and Management, 131(8), 890-902. https://doi.org/https://doi.org/10.106 1/(ASCE)07339364(2005)131:8(890)

Nassar, K. M., Nassar, W. M., \& Hegab, M. Y. (2005). Evaluating Cost Overruns of Asphalt Paving Project Using Statistical Process Control Methods. Journal of Construction Engineering and Management, 131(11), 11731178.

https://doi.org/https://doi.org/10.106 1/(ASCE)07339364(2005)131:11(1173)

Serag, E., Oloufa, A., Malone, L., \& Radwan, E. (2010). Model for Quantifying the Impact of Change Orders on Project Cost for U.S. Roadwork Construction. Journal of Construction Engineering and Management, 136(9), 1015-1027. https://doi.org/10.1061/_ASCECO.1 943-7862.0000206

Sulistio, H., \& Waty, M. (2008). Analysis and Evaluation Change Order in Flexible Pavement (Case Study: Road Projects in East Kalimantan). MEDIA KOMUNIKASI TEKNIK SIPIL, 16(1), 31-47. https://doi.org/https://doi.org/10.147 10/mkts.v16i1.3664

Taylor, T. R. B., Uddin, M., Goodrum, P. M., McCoy, A., \& Shan, Y. (2012). Change Orders and Lessons Learned: Knowledge from Statistical Analyses of Engineering Change Orders on Kentucky Highway Projects. Journal of Construction Engineering and Management, 138(12), 1360-1369. https://doi.org/10.1061/(ASCE)CO.1 943-7862.0000550 
Waty, M., \& Sulistio, H. (2020). Perhitungan Change Order Proyek Jalan di Banten. Jurnal Muara Sains, Teknologi, Kedokteran Dan Ilmu Kesehatan, 4(2), 211. https://doi.org/10.24912/jmstkik.v4i2 .6342

Wu, Chao-hui, Hsieh, T., \& Cheng, W. (2005). Statistical analysis of causes for design change in highway construction on Taiwan. International Journal of Project Management, 23(7), 554-563. https://doi.org/10.1016/j.ijproman.20 04.07.010

Wu, Chao- Hui, Hsieh, T., Cheng, W., \& Lu, S. (2004). Grey relation analysis of causes for change orders in highway construction. Construction Management and Economics, 22(5), 509-520.

https://doi.org/10.1080/01446190420 00202735

Yana, A. A. G. A., Rusdhi, H. A., \& Wibowo, M. A. (2015). Analysis of Factors Affecting Design Changes in Construction Project with Partial Least Square (PLS). Procedia Engineering, 125, 40-45. https://doi.org/10.1016/j.proeng.2015 .11 .007 